\title{
REVIEW
}

\section{The $\beta$-secretase enzyme BACE1 as a therapeutic target for Alzheimer's disease}

\author{
Robert Vassar* and Patty C Kandalepas
}

\begin{abstract}
Amyloid plaques are defining histopathologic lesions in the brains of Alzheimer's disease (AD) patients and are composed of the amyloid-beta peptide, which is widely considered to play a critical role in the pathogenesis of AD. The $\beta$-secretase, or $\beta$-site amyloid precursor protein cleaving enzyme 1 (BACE1; also called Asp2, memapsin 2), is the enzyme that initiates the generation of amyloid beta. Consequently, BACE1 is an attractive drug target for lowering cerebral levels of amyloid beta for the treatment or prevention of AD. Much has been learned about BACE1 since its discovery over 10 years ago. In the present article, we review BACE1 properties and characteristics, cell biology, in vivo validation, substrates, therapeutic potential, and inhibitor drug development. Studies relating to the physiological functions of BACE1 and the promise of BACE1 inhibition for AD will also be discussed. We conclude that therapeutic inhibition of BACE1 should be efficacious for AD, although careful titration of the drug dose may be necessary to limit mechanism-based side effects.
\end{abstract}

\section{Discovery of BACE1, the Alzheimer's $\boldsymbol{\beta}$-secretase}

Autosomal dominant mutations in the genes for amyloid precursor protein (APP) and the presenilins (presenilin-1 and presenilin-2) cause familial Alzheimer's disease (AD) (reviewed in [1]), and these findings together with others suggest that the amyloid-beta $(A \beta)$ peptide plays a central role in $\mathrm{AD}$ pathogenesis. Consequently, therapeutic approaches to lower brain $A \beta$ levels should be efficacious for the treatment or prevention of $\mathrm{AD}$. $\mathrm{A} \beta$ is generated through the sequential endoproteolysis of APP by the $\beta$-secretase and $\gamma$-secretase enzymes (reviewed in [2]). $\beta$-secretase cuts first at the $\mathrm{N}$-terminus of $A \beta ; \gamma$-secretase cleaves only thereafter to make the C-terminus of $A \beta$.

*Correspondence: r-vassar@northwestern.edu

Department of Cell \& Molecular Biology, Feinberg School of Medicine, Northwestern University, 300 E. Superior, Tarry 8-713, Chicago, IL 60611, USA
Then $A \beta$ is secreted from neurons to form amyloid plaques in the $\mathrm{AD}$ brain. Inhibition of $\beta$-secretase should thus decrease production of $A \beta$, the pathogenic form of the peptide.

Since the discovery of $A \beta$, the molecular identity of the $\beta$-secretase has been intensely sought because of its prime status as a drug target for $\mathrm{AD}$. Prior to the enzyme's discovery, the properties of $\beta$-secretase activity in cells and tissues had been extensively characterized. In 1999 five groups reported the molecular cloning of the $\beta$-secretase [3], variously naming the enzyme BACE [4], Asp2 [5,6], or memapsin 2 [7] (herein, $\beta$-secretase will be referred to as $\beta$-site amyloid precursor protein cleaving enzyme 1 (BACE1)). The groups used different isolation methods (expression cloning, protein purification, genomics), yet all identified the same enzyme and agreed it possessed all the characteristics of $\beta$-secretase.

\section{BACE1 cell biology}

BACE1 is a type 1 transmembrane aspartic protease related to the pepsins and retroviral aspartic proteases [3-7]. BACE1 activity has a low optimum $\mathrm{pH}$ [4], and the enzyme is predominantly localized in acidic intracellular compartments (for example, endosomes, trans-Golgi) with its active site in the lumen of the vesicle [3-8]. The highest expression levels of BACE1 are found in neurons $[3,4]$. Importantly, BACE1 overexpression or BACE1 knockdown increases or decreases production of $A \beta$ and $\beta$-secretase-cleaved APP fragments, respectively [4]. In addition, the activity of BACE1 on wild-type and mutant APP substrates is consistent with the sequence specificity of $\beta$-secretase. For example, BACE1 cleaves APP with the Swedish familial AD-causing mutation (APPswe) $\sim 10$-fold to 100 -fold more efficiently than wild-type APP $[3,4,9]$.

BACE1 is synthesized as a 501-amino-acid zymogen (containing a short prodomain) in the endoplasmic reticulum $[3-7,10]$. Within the lumen of the endoplasmic reticulum, BACE1 is subjected to simple glycosylation on four Asn residues [11] and transient acetylation on seven Arg residues [12]. Further addition of complex carbohydrates and removal of the BACE1 prodomain by furin convertases occur in the Golgi compartment [13-16]. 
BACE1 is phosphorylated on Ser 498, and this phosphorylation together with a C-terminal acidic cluster dileucine motif (DXXLL) regulates BACE1 recycling between the cell surface and endosomal compartments [17-19].

BACE1 is S-palmitoylated on four Cys residues located at the junction of the transmembrane and cytosolic domains $[15,20]$, and this modification facilitates BACE1 partitioning into lipid rafts. Increased targeting of BACE1 to the lipid raft was suggested to enhance $\beta$-secretase processing of APP [21,22]. A recent study, however, reported that nonraft-localized palmitoylation-deficient BACE1 is equally active in APP processing and A $\beta$ secretion as is raft-associated palmitoylated BACE1 [20]. Although BACE1 can process APP in both raft and nonraft environments, a membrane-anchored version of a BACE1 transition-state inhibitor produced by linkage to a sterol moiety appeared more potent as a result of targeting to lipid rafts [23].

Golgi-localized $\gamma$-ear-containing ARF-binding (GGA) proteins interact with the BACE1 C-terminal DXXLL motif via a VHL domain and regulate trafficking of BACE1 between the late Golgi and early endosomes [24-26]. Depletion of GGA proteins by RNAi or disruption of phosphorylation of BACE1 on Ser498 increases accumulation of BACE1 in early endosomes, an acidic environment that favors BACE1 cleavage of APP and subsequent $A \beta$ production [27-29]. Interestingly, GGA3 is a caspase- 3 substrate and is degraded during neuronal apoptosis. In the brains of AD patients, in which neuronal apoptosis may occur, the levels of GGA3 are significantly decreased [28]. Reduced GGA3 levels not only increase localization of BACE1 to early endosomes, but also stabilize BACE1 by preventing its trafficking to lysosomes where it is degraded.

Intracellular localization of BACE1 can be altered by other regulatory factors in addition to the GGA proteins. Reticulon/Nogo family members have been identified as negative regulators of BACE1 [30,31]. Overexpression of reticulon proteins results in prolonged BACE1 retention in the endoplasmic reticulum with concomitant decrease in BACE1-mediated APP cleavage [32]. Sorting nexin 6 is another BACE1-associated protein that influences BACE1 subcellular localization and acts as a negative regulator of BACE1 activity [33]. Inhibition of sorting nexin 6 increases $A \beta$ as well as retrograde transport of BACE1 to the trans-Golgi network. Sortilin is the most recently identified modulator of BACE1 trafficking [34]. When overexpressed, sortilin increases BACE1-mediated APP cleavage, while RNAi-mediated knockdown decreases A $\beta$. Future studies aimed at identifying the BACE1 interactome will yield fruitful information regarding novel proteins that control BACE1 trafficking, and hence $A \beta$ production, which in turn could represent potential $A D$ therapeutic targets.

\section{In vivo validation of $B A C E 1$}

Soon after BACE1 was discovered, its homolog BACE2 was identified [5,35]. BACE1 and BACE2 shared 64\% amino acid sequence similarity, which suggested BACE2 was also a $\beta$-secretase. BACE2 was expressed at low levels in neurons and did not have the same cleavage activity as $\beta$-secretase, however, indicating it was a poor $\beta$-secretase candidate. To demonstrate that BACE1 was the $\beta$-secretase in vivo, $B A C E^{-/-}$mice were generated [3639]. Initial reports indicated that $B A C E 1^{-/-}$mice were viable and fertile, suggesting that therapeutic inhibition of BACE1 might be free of mechanism-based side effects. Recent studies, however, have shown that $B A C E 1^{-/-}$mice are not completely normal (discussed below).

Importantly, $A \beta$ production, amyloid pathology, electrophysiological dysfunction, and cognitive deficits were prevented when $B A C E 1^{-/-}$mice were bred to APP transgenic mice [36,40-43]. Moreover, lentiviral delivery of BACE1 RNAi attenuated $A \beta$ amyloidosis and cognitive deficits in APP transgenics $[43,44]$. These results demonstrated that BACE1 is the major, if not only, $\beta$-secretase enzyme in the brain. Taken together, BACE1 characterization and validation studies have unequivocally demonstrated that BACE1 is the authentic $\beta$-secretase in the brain and that it is a promising therapeutic target for lowering cerebral $A \beta$ levels.

\section{BACE1 substrates}

In addition to APP, BACE1 has other substrates (Table 1), and identification of these substrates is useful not only for evaluation of potential mechanism-based toxicity arising from inhibition of BACE1 but also for designing potent and selective BACE1 inhibitors. Moreover, the diverse list of BACE1 substrates suggests a variety of BACE1 physiological functions.

All known BACE1 substrates are transmembrane proteins, such as Golgi-localized membrane-bound $\alpha 2,6-$ sialyltransferase $[45,46]$, IL-1 type II receptor [47], Pselectin glycoprotein ligand-1 [48], APP homologs A $\beta$ precursor-like protein- 1 and $A \beta$ precursor-like protein- 2 [49-51], low-density lipoprotein receptor-related protein $[51,52]$, the voltage-gated sodium channel $\beta 1$ to $\beta 4$ subunits [53-55], neuregulin-1 [56,57] and neuregulin-3 [58]. Recently, an unbiased screen for novel BACE1 substrates identified 64 type I transmembrane proteins, three glycophosphatidylinositol-linked proteins and one type II transmembrane protein [51]. Although the majority of these putative BACE1 substrates have not been validated, several were found to be cleaved by BACE1 in cell culture, including ephrin type A receptor 5, Golgi phosphoprotein-4, leucine-rich repeats and immunoglobulinlike domain protein-2 (and -3), insulin-like growth factor 2 receptor and semaphorin-4C. Further studies will be required to determine whether these proteins are BACE1 
Table 1. Validated BACE1 substrates and potential mechanism-based toxicity arising from BACE1 inhibition

\begin{tabular}{ll}
\hline Substrate & Toxicity \\
\hline APP, APLP1 and APLP2 & Impaired cell-cell signaling, injury recovery, synaptic function, memory \\
ILIR2 & Abnormal inflammatory response \\
LRP & Impairments in lipid metabolism, degradation of proteases and activation of lysosomal enzymes \\
$\mathrm{Na}_{\mathbf{v}} \beta_{1-4}$ & Altered neuronal excitability [76] \\
Neuregulin-1 and neuregulin-3 & Impaired remyelination following nerve injury [58] \\
PSGL-1 & Altered leukocyte recruitment during innate and adaptive immune response [77] \\
ST6Gal I & Hepatopathology, B-cell dysfunction \\
\hline
\end{tabular}

APLP, amyloid beta precursor-like protein; APP, amyloid precursor protein; BACE1, $\beta$-site amyloid precursor protein cleaving enzyme 1; IL1R2, IL-1 type II receptor; LRP, low-density lipoprotein receptor-related protein; $\mathrm{Na}_{v} \beta_{1-4^{\prime}}$ voltage-gated sodium channel $\beta 1$ to $\beta 4$ subunits; PSGL-1, P-selectin glycoprotein ligand-1; ST6Gal I, Golgilocalized membrane-bound $\beta$-galactoside $\alpha 2,6$-sialyltransferase.

substrates at endogenous levels in vivo. Additional BACE1 substrates are likely to be discovered in the future.

\section{BACE1 as a therapeutic target for Alzheimer's disease}

Although $B A C E 1^{-/-}$mice appear viable and fertile, the growing list of BACE1 substrates has suggested that less obvious phenotypes related to deficient BACE1 processing of substrates may exist. Indeed, eliminating BACE1 cleavage of neuregulin-1 in $B A C E 1^{-/}$mice causes reduced myelin sheath thickness of axons of both peripheral sciatic nerves $[56,57]$ and central optic nerves [56]. $B A C E 1^{-/-}$mice also display retarded remyelination of injured sciatic nerves [58]. In addition, recent studies have demonstrated that $B A C E 1^{-/-}$mice exhibit increased frequency of spontaneous and kainite-induced seizures [59-61]. Hypomyelination and increased seizures observed in $B A C E 1^{-/}$mice have raised concerns that therapeutic BACE1 inhibition may be associated with similar untoward effects in humans. However, whether the hypomyelination and seizure phenotypes in $B A C E 1^{-/-}$ mice are caused by the lack of BACE1 activity in the adult or during embryonic or postnatal development is currently unknown.

Because of potential adverse side effects associated with strong inhibition or reduction of BACE1, investigators have tested whether a moderate decrease in BACE1 activity would provide benefits in the central nervous system while limiting mechanism-based toxicities. Laird and coworkers showed a significant reduction of $A \beta$ deposition in brains of 12-month-old APPswe;PS1DE9;BACE1 $1^{+/-}$mice as compared with that of $A P P s w e ; P S 1 D E 9 ; B A C E 1^{+/+}$mice; however, no significant differences were observed in brains of 20-month-old APPswe;PS1DE9;BACE1+/- animals [43]. It is unclear why the older mice in this study did not show reduced amyloidosis. In a similar study, McConlogue and colleagues reported a significantly reduced $A \beta$ burden in the brains of 13-month-old and 18-month-old
PDAPP;BACE1 ${ }^{+-}$mice [62]. Although the two studies had differences, neither indicated a negative phenotype associated with the $B A C E 1^{+/-}$mice. Taken together, these data suggest the exciting possibility that partial inhibition of BACE1 may effectively reduce $A \beta$ deposition without mechanism-based toxicity.

\section{BACE1 inhibitor development}

Since the identification of BACE1, intense efforts have been underway to develop small-molecule BACE1 inhibitors as drugs for AD. First-generation BACE1 inhibitors were peptide-based mimetics (peptidomimetics) of the APP $\beta$-site that replaced the scissile amide bond with a nonhydrolizable transition state analog such as statine [3]. The X-ray structure of BACE1 cocrystallized with peptidomimetic inhibitors [63] greatly facilitated the rational design of BACE1 inhibitors. More recently, later-generation nonpeptidic compounds with low nanomolar half-maximal inhibitory concentration potencies have been generated (reviewed in [64-66]).

Although initial drug development efforts with peptidomimetic BACE1 inhibitors were encouraging, BACE1 has since proven to be a challenging medicinal chemistry target. There appear to be several reasons for this challenge. First, BACE1 has a large hydrophobic substrate-binding site designed to fit polypeptides, thus making it difficult to inhibit the enzyme with small nonpeptidic compounds that have desirable drug-like characteristics. Ideally, BACE1 inhibitor drugs should be of a molecular weight $<500$, orally bioavailable, metabolically stable, intrinsically potent, and highly selective for BACE1 over BACE2 and other aspartic proteases. This latter point is relevant because $\mathrm{BACE} 1^{-/-} ; \mathrm{BACE} 2^{-/-}$ double knockout mice have enhanced postnatal lethality compared with $\mathrm{BACE}^{-/-}$single knockout mice [39]. Compounds must also be hydrophobic enough to penetrate both plasma and intracellular membranes to gain access to the lumen of the compartment where the BACE1 active site is localized. Finally, efficacious BACE1 drugs would need to efficiently cross the blood-brain 
barrier and achieve a high concentration in the cerebral parenchyma.

Despite these challenges, potent nonpeptidic smallmolecule BACE1 inhibitors have shown success in lowering cerebral $A \beta$ levels in mouse [67-69], hamster [70] and primate [71] models. Moreover, the biopharmaceutical company CoMentis (South San Francisco, CA, USA) recently announced the completion of the first human phase 1 clinical trial of a BACE1 inhibitor drug [72]. Other BACE1 inhibitor drug candidates will probably soon be entering into human clinical trials. An interesting alternative to small-molecule inhibitors entails the use of monoclonal antibodies to inhibit BACE1 enzymatic activity. Recent reports hint at the potential of antibodies that inhibit BACE1 cleavage of APP by either directly binding to BACE1 [73] or by binding to the $\beta$-secretase cleavage site of APP [74]. The latter has shown in vivo efficacy for decreasing $A \beta$ in a murine model [75]. These encouraging results suggest that therapeutic approaches involving BACE1 inhibition for the treatment or prevention of AD may be a reality in the future. Given recent data hinting at important physiological roles for BACE1, however, careful titration of the BACE1 drug dosage may be necessary to minimize mechanism-based side effects.

\section{Conclusions}

Since the discovery of BACE1 over a decade ago, our knowledge about this enzyme has increased significantly. Progress has been made toward the development of small-molecule inhibitors capable of penetrating the blood-brain barrier and having sufficient potency to inhibit $\mathrm{A} \beta$ generation in vivo. There is also very early evidence for the prospect of anti-BACE1 monoclonal antibodies for AD treatment. Despite promising news of BACE1 inhibitor development, however, BACE1 therapeutics for routine $A D$ treatment are not yet available. Although BACE1 small-molecule inhibitor medicinal chemistry and pharmacokinetics have proven challenging, the recent entry of at least one BACE1 inhibitor into clinical trial is an encouraging advance toward BACE1 therapeutic inhibition for the treatment of AD. Drugmakers and physicians should keep in mind that BACE1 appears to have important physiological functions, perhaps requiring careful titration of the BACE1 inhibitor drug dose to minimize potential mechanismbased toxicity. Finally, advancing our understanding of the roles of BACE1 in health and disease will facilitate the development of novel therapies for $\mathrm{AD}$ and may shed light on the etiology of this devastating disease and other disorders of the nervous system.

\section{Abbreviations}

AD, Alzheimer's disease; APP, amyloid precursor protein; APP , amyloid precursor protein with the Swedish familial Alzheimer's disease-causing mutation; $A \beta$, amyloid beta; $B A C E 1, \beta$-site amyloid precursor protein cleaving enzyme 1; GGA, Golgi-localized $\gamma$-ear-containing ARF-binding protein; IL, interleukin; RNAi, RNA interference.

\section{Competing interests}

The authors declare that they have no competing interests.

\section{Published: 31 May 2011}

\section{References}

1. Sisodia SS, St George-Hyslop PH: $\boldsymbol{Y}$-Secretase, Notch, Abeta and Alzheimer's disease: where do the presenilins fit in? Nat Rev Neurosci 2002, 3:281-290.

2. Tanzi RE, Bertram L: Twenty years of the Alzheimer's disease amyloid hypothesis: a genetic perspective. Cell 2005, 120:545-555.

3. Sinha S, Anderson JP, Barbour R, Basi GS, Caccavello R, Davis D, Doan M, Dovey HF, Frigon N, Hong J, Jacobson-Croak K, Jewett N, Keim P, Knops J, Lieberburg I, Power M, Tan H, Tatsuno G, Tung J, Schenk D, Seubert P, Suomensaari SM, Wang S, Walker D, Zhao J, McConlogue L, John V: Purification and cloning of amyloid precursor protein $\beta$-secretase from human brain. Nature 1999, 402:537-540.

4. Vassar R, Bennett BD, Babu-Khan S, Kahn S, Mendiaz EA, Denis P, Teplow DB, Ross S, Amarante P, Loeloff R, Luo Y, Fisher S, Fuller J, Edenson S, Lile J, Jarosinski MA, Biere AL, Curran E, Burgess T, Louis JC, Collins F, Treanor J, Rogers G, Citron M: Beta-secretase cleavage of Alzheimer's amyloid precursor protein by the transmembrane aspartic protease BACE. Science 1999, 286:735-741.

5. Yan R, Bienkowski MJ, Shuck ME, Miao H, Tory MC, Pauley AM, Brashier JR, Stratman NC, Mathews WR, Buhl AE, Carter DB, Tomasselli AG, Parodi LA, Heinrikson RL, Gurney ME: Membrane-anchored aspartyl protease with Alzheimer's disease $\beta$-secretase activity. Nature 1999, 402:533-537.

6. Hussain I, Powell D, Howlett DR, Tew DG, Meek TD, Chapman C, Gloger IS, Murphy KE, Southan CD, Ryan DM, Smith TS, Simmons DL, Walsh FS, Dingwall C, Christie G: Identification of a novel aspartic protease (Asp 2) as $\beta$ secretase. Mol Cell Neurosci 1999, 14:419-427.

7. Lin X, Koelsch G, Wu S, Downs D, Dashti A, Tang J: Human aspartic protease memapsin 2 cleaves the $\beta$-secretase site of $\beta$-amyloid precursor protein. Proc Natl Acad Sci U S A 2000, 97:1456-1460.

8. Kinoshita A, Fukumoto H, Shah T, Whelan CM, Irizarry MC, Hyman BT: Demonstration by FRET of BACE interaction with the amyloid precursor protein at the cell surface and in early endosomes. J Cell Sci 2003, 116:3339-3346.

9. Citron M, Oltersdorf T, Haass C, McConlogue L, Hung AY, Seubert P, VigoPelfrey C, Lieberburg I, Selkoe DJ: Mutation of the $\beta$-amyloid precursor protein in familial Alzheimer's disease increases $\beta$-protein production. Nature 1992, 360:672-674.

10. Capell A, Steiner H, Willem M, Kaiser H, Meyer C, Walter J, Lammich S, Multhaup G, Haass C: Maturation and pro-peptide cleavage of $\beta$-secretase. J Biol Chem 2000, 275:30849-30854.

11. Haniu M, Denis P, Young Y, Mendiaz EA, Fuller J, Hui JO, Bennett BD, Kahn S, Ross S, Burgess T, Katta V, Rogers G, Vassar R, Citron M: Characterization of Alzheimer's $\beta$-secretase protein BACE. A pepsin family member with unusual properties. J Biol Chem 2000, 275:21099-21106.

12. Costantini $C, K o M H$, Jonas MC, Puglielli L: A reversible form of lysine acetylation in the ER and Golgi lumen controls the molecular stabilization of BACE1. Biochem J 2007, 407:383-395.

13. Capell A, Steiner H, Willem M, Kaiser H, Meyer C, Walter J, Lammich S, Multhaup G, Haass C: Maturation and pro-peptide cleavage of $\beta$-secretase. J Biol Chem 2000, 275:30849-30854.

14. Bennett BD, Denis P, Haniu M, Teplow DB, Kahn S, Louis JC, Citron M, Vassar R: A furin-like convertase mediates propeptide cleavage of $B A C E$, the Alzheimer's $\beta$-secretase. J Biol Chem 2000, 275:37712-37717.

15. Benjannet S, Elagoz A, Wickham L, Mamarbachi M, Munzer JS, Basak A, Lazure C, Cromlish JA, Sisodia S, Checler F, Chretien M, Seidah NG: Post-translational processing of $\beta$-secretase ( $\beta$-amyloid-converting enzyme) and its ectodomain shedding. The pro- and transmembrane/cytosolic domains affect its cellular activity and amyloid- $\beta$ production. J Bio/ Chem 2001 , 276:10879-10887.

16. Creemers JW, Ines Dominguez D, Plets E, Serneels L, Taylor NA, Multhaup G, Craessaerts K, Annaert W, De Strooper B: Processing of $\beta$-secretase by furin and other members of the proprotein convertase family. J Biol Chem 2001, 276:4211-4217. 
17. Huse JT, Pijak DS, Leslie GJ, Lee VM, Doms RW: Maturation and endosomal targeting of $\beta$-site amyloid precursor protein-cleaving enzyme. The Alzheimer's disease $\beta$-secretase. J Biol Chem 2000, 275:33729-33737.

18. Walter J, Fluhrer R, Hartung B, Willem M, Kaether C, Capell A, Lammich S, Multhaup G, Haass C: Phosphorylation regulates intracellular trafficking of ß-secretase. J Biol Chem 2001, 276:14634-14641.

19. Pastorino L, Ikin AF, Nairn AC, Pursnani A, Buxbaum JD: The carboxylterminus of BACE contains a sorting signal that regulates BACE trafficking but not the formation of total A $\beta$. Mol Cell Neurosci 2002, 19:175-185.

20. Vetrivel KS, Meckler X, Chen Y, Nguyen PD, Seidah NG, Vassar R, Wong PC, Fukata M, Kounnas MZ, Thinakaran G: Alzheimer disease $A \beta$ production in the absence of S-palmitoylation-dependent targeting of BACE1 to lipid rafts. J Biol Chem 2009, 284:3793-3803.

21. Cordy JM, Hussain I, Dingwall C, Hooper NM, Turner AJ: Exclusively targeting $\beta$-secretase to lipid rafts by GPI-anchor addition up-regulates $\beta$-site processing of the amyloid precursor protein. Proc Natl Acad Sci U S A 2003, 100:11735-11740

22. Tun H, Marlow L, Pinnix I, Kinsey R, Sambamurti K: Lipid rafts play an important role in $A \beta$ biogenesis by regulating the $\beta$-secretase pathway. J Mol Neurosci 2002, 19:31-35.

23. Rajendran L, Schneider A, Schlechtingen G, Weidlich S, Ries J, Braxmeier T, Schwille P, Schulz JB, Schroeder C, Simons M, Jennings G, Knolker HJ, Simons $\mathrm{K}$ : Efficient inhibition of the Alzheimer's disease $\beta$-secretase by membrane targeting. Science 2008, 320:520-523.

24. He X, Chang WP, Koelsch G, Tang J: Memapsin 2 ( $\beta$-secretase) cytosolic domain binds to the VHS domains of GGA1 and GGA2: implications on the endocytosis mechanism of memapsin 2. FEBS Lett 2002, 524:183-187.

25. He X, Zhu G, Koelsch G, Rodgers KK, Zhang XC, Tang J: Biochemical and structural characterization of the interaction of memapsin 2 ( $\beta$-secretase) cytosolic domain with the VHS domain of GGA proteins. Biochemistry 2003, 42:12174-12180.

26. von Arnim CA, Tangredi MM, Peltan ID, Lee BM, Irizarry MC, Kinoshita A, Hyman BT: Demonstration of BACE ( $\beta$-secretase) phosphorylation and its interaction with GGA1 in cells by fluorescence-lifetime imaging microscopy. J Cell Sci 2004, 117:5437-5445.

27. He X, Li F, Chang WP, Tang J: GGA proteins mediate the recycling pathway of memapsin 2 (BACE). J Biol Chem 2005, 280:11696-11703.

28. Tesco G, Koh YH, Kang EL, Cameron AN, Das S, Sena-Esteves M, Hiltunen M, Yang SH, Zhong Z, Shen Y, Simpkins JW, Tanzi RE: Depletion of GGA3 stabilizes BACE and enhances $\beta$-secretase activity. Neuron 2007, 54:721-737

29. Wahle T, Prager K, Raffler N, Haass C, Famulok M, Walter J: GGA proteins regulate retrograde transport of BACE1 from endosomes to the transGolgi network. Mol Cell Neurosci 2005, 29:453-461.

30. He W, Lu Y, Qahwash I, Hu XY, Chang A, Yan R: Reticulon family members modulate BACE1 activity and amyloid- $\beta$ peptide generation. Nat Med 2004, 10:959-965.

31. Murayama KS, Kametani F, Saito S, Kume H, Akiyama H, Araki W: Reticulons RTN3 and RTN4-B/C interact with BACE1 and inhibit its ability to produce amyloid $\beta$-protein. Eur J Neurosci 2006, 24:1237-1244

32. Shi Q, Prior M, He W, Tang X, Hu X, Yan R: Reduced amyloid deposition in mice overexpressing RTN3 is adversely affected by preformed dystrophic neurites. J Neurosci 2009, 29:9163-9173.

33. Okada H, Zhang W, Peterhoff C, Hwang JC, Nixon RA, Ryu SH, Kim TW: Proteomic identification of sorting nexin 6 as a negative regulator of BACE1-mediated APP processing. Faseb J 2010, 24:2783-2794.

34. Finan $\mathrm{GM}$, Okada $\mathrm{H}$, Kim TW: BACE1 retrograde trafficking is uniquely regulated by the cytoplasmic domain of sortilin. J Bio/ Chem 2011, 286:12602-12616

35. Saunders A, Kim T-W, Tanzi RE: BACE maps to chromosome 11 and a BACE homolog, BACE2, reside in the obligate Down syndrome region of chromosome 21. Science 1999, 286:1255a.

36. Luo Y, Bolon B, Kahn S, Bennett BD, Babu-Khan S, Denis P, Fan W, Kha H, Zhang J, Gong Y, Martin L, Louis JC, Yan Q, Richards WG, Citron M, Vassar R: Mice deficient in BACE1, the Alzheimer's $\beta$-secretase, have normal phenotype and abolished $\beta$-amyloid generation. Nat Neurosci 2001, 4:231-232.

37. Cai $H$, Wang $Y, M c C$ arthy $D$, Wen $H$, Borchelt DR, Price DL, Wong PC: BACE1 is the major $\beta$-secretase for generation of $A \beta$ peptides by neurons. Nat Neurosci 2001, 4:233-234.

38. Roberds SL, Anderson J, Basi G, Bienkowski MJ, Branstetter DG, Chen KS, Freedman SB, Frigon NL, Games D, Hu K, Johnson-Wood K, Kappenman KE,
Kawabe TT, Kola I, Kuehn R, Lee M, Liu W, Motter R, Nichols NF, Power M, Robertson DW, Schenk D, Schoor M, Shopp GM, Shuck ME, Sinha S, Svensson KA, Tatsuno G, Tintrup H, Wijsman J, et al.: BACE knockout mice are healthy despite lacking the primary $\beta$-secretase activity in brain: implications for Alzheimer's disease therapeutics. Hum Mol Genet 2001, 10:1317-1324.

39. Dominguez D, Tournoy J, Hartmann D, Huth T, Cryns K, Deforce S, Serneels L, Camacho IE, Marjaux E, Craessaerts K, Roebroek AJ, Schwake M, D'Hooge R, Bach P, Kalinke U, Moechars D, Alzheimer C, Reiss K, Saftig P, De Strooper B: Phenotypic and biochemical analyses of BACE1- and BACE2-deficient mice. J Biol Chem 2005, 280:30797-30806.

40. Ohno M, Sametsky EA, Younkin LH, Oakley H, Younkin SG, Citron M, Vassar R, Disterhoft JF: BACE1 deficiency rescues memory deficits and cholinergic dysfunction in a mouse model of Alzheimer's disease. Neuron 2004, 41:27-33.

41. Ohno M, Cole SL, Yasvoina M, Zhao J, Citron M, Berry R, Disterhoft JF, Vassar R: BACE1 gene deletion prevents neuron loss and memory deficits in 5XFAD APP/PS1 transgenic mice. Neurobiol Dis 2007, 26:134-145.

42. Luo Y, Bolon B, Damore MA, Fitzpatrick D, Liu H, Zhang J, Yan Q, Vassar R, Citron M: BACE1 ( $\beta$-secretase) knockout mice do not acquire compensatory gene expression changes or develop neural lesions over time. Neurobiol Dis 2003, 14:81-88.

43. Laird FM, Cai H, Savonenko AV, Farah MH, He K, Melnikova T, Wen $\mathrm{H}$, Chiang HC, Xu G, Koliatsos VE, Borchelt DR, Price DL, Lee HK, Wong PC: BACE1, a major determinant of selective vulnerability of the brain to amyloid- $\beta$ amyloidogenesis, is essential for cognitive, emotional, and synaptic functions. J Neurosci 2005, 25:11693-11709.

44. Singer O, Marr RA, Rockenstein E, Crews L, Coufal NG, Gage FH, Verma IM, Masliah E: Targeting BACE1 with siRNAs ameliorates Alzheimer disease neuropathology in a transgenic model. Nat Neurosci 2005, 8:1343-1349.

45. Kitazume S, Nakagawa K, Oka R, Tachida Y, Ogawa K, Luo Y, Citron M, Shitara H, Taya C, Yonekawa H, Paulson JC, Miyoshi E, Tanguchi N, Hashimoto Y: In vivo cleavage of alpha 2,6-sialyltransferase by Alzheimer $\beta$-secretase. J Bio Chem 2005, 280:8589-8595.

46. Kitazume S, Tachida Y, Oka R, Shirotani K, Saido TC, Hashimoto Y: Alzheimer's $\beta$-secretase, $\beta$-site amyloid precursor protein-cleaving enzyme, is responsible for cleavage secretion of a Golgi-resident sialyltransferase. Proc Natl Acad Sci U S A 2001, 98:13554-13559.

47. Kuhn PH, Marjaux E, Imhof A, De Strooper B, Haass C, Lichtenthaler SF: Regulated intramembrane proteolysis of the interleukin-1 receptor II by $\alpha-, \beta$-, and $\gamma$-secretase. J Bio/ Chem 2007, 282:11982-11995.

48. Lichtenthaler SF, Dominguez DI, Westmeyer GG, Reiss K, Haass C, Saftig P, De Strooper B, Seed B: The cell adhesion protein P-selectin glycoprotein ligand- 1 is a substrate for the aspartyl protease BACE1. J Biol Chem 2003 278:48713-48719.

49. Li Q, Sudhof TC: Cleavage of amyloid- $\beta$ precursor protein and amyloid- $\beta$ precursor-like protein by BACE 1. J Biol Chem 2004, 279:10542-10550.

50. Pastorino L, Ikin AF, Lamprianou S, Vacaresse N, Revelli JP, Platt K, Paganetti $P$, Mathews PM, Harroch S, Buxbaum JD: BACE ( $\beta$-secretase) modulates the processing of APLP2 in vivo. Mol Cell Neurosci 2004, 25:642-649.

51. Hemming ML, Elias JE, Gygi SP, Selkoe DJ: Identification of $\beta$-secretase (BACE1) substrates using quantitative proteomics. PLoS One 2009, 4:e8477.

52. von Arnim CA, Kinoshita A, Peltan ID, Tangredi MM, Herl L, Lee BM, Spoelgen R, Hshieh TT, Ranganathan S, Battey FD, Liu CX, Bacskai BJ, Sever S, Irizarry MC, Strickland DK, Hyman BT: The low density lipoprotein receptor-related protein (LRP) is a novel $\beta$-secretase (BACE1) substrate. J Biol Chem 2005, 280:17777-17785.

53. Wong HK, Sakurai T, Oyama F, Kaneko K, Wada K, Miyazaki H, Kurosawa M, De Strooper B, Saftig P, Nukina N: $\beta$ Subunits of voltage-gated sodium channels are novel substrates of $\beta$-site amyloid precursor protein-cleaving enzyme (BACE1) and $\gamma$-secretase. J Biol Chem 2005, 280:23009-23017.

54. Kim DY, Ingano LA, Carey BW, Pettingell WH, Kovacs DM: Presenilin/ $\gamma$-secretase-mediated cleavage of the voltage-gated sodium channel $\beta 2$-subunit regulates cell adhesion and migration. J Biol Chem 2005, 280:23251-23261.

55. Kim DY, Carey BW, Wang H, Ingano LA, Binshtok AM, Wertz MH, Pettingell WH, He P, Lee VM, Woolf CJ, Kovacs DM: BACE1 regulates voltage-gated sodium channels and neuronal activity. Nat Cell Bio/ 2007, 9:755-764

56. Hu X, Hicks CW, He W, Wong P, Macklin WB, Trapp BD, Yan R: Bace1 modulates myelination in the central and peripheral nervous system. Nat Neurosci 2006, 9:1520-1525

57. Willem M, Garratt AN, Novak B, Citron M, Kaufmann S, Rittger A, DeStrooper B, 
Saftig P, Birchmeier C, Haass C: Control of peripheral nerve myelination by the $\beta$-secretase BACE1. Science 2006, 314:664-666.

58. Hu X, He W, Diaconu C, Tang X, Kidd GJ, Macklin WB, Trapp BD, Yan R: Genetic deletion of BACE1 in mice affects remyelination of sciatic nerves. FASEB J 2008, 22:2970-2980.

59. Hitt BD, Jaramillo TC, Chetkovich DM, Vassar R: BACE1 ${ }^{-/-}$mice exhibit seizure activity that does not correlate with sodium channel level or axonal Iocalization. Mol Neurodegener 2010, 5:31-34

60. Hu X, Zhou X, He W, Yang J, Xiong W, Wong P, Wilson CG, Yan R: BACE1 deficiency causes altered neuronal activity and neurodegeneration. J Neurosci 2010, 30:8819-8829.

61. Kobayashi D, Zeller M, Cole T, Buttini M, McConlogue L, Sinha S, Freedman S, Morris RG, Chen KS: BACE1 gene deletion: impact on behavioral function in a model of Alzheimer's disease. Neurobiol Aging 2008, 29:861-873.

62. McConlogue L, Buttini M, Anderson JP, Brigham EF, Chen KS, Freedman SB, Games D, Johnson-Wood K, Lee M, Zeller M, Liu W, Motter R, Sinha S: Partial reduction of BACE1 has dramatic effects on Alzheimer plaque and synaptic pathology in APP transgenic mice. J Biol Chem 2007, 282:26326-26334

63. Hong L, Turner RT, 3rd, Koelsch G, Shin D, Ghosh AK, Tang J: Crystal structure of memapsin 2 ( $\beta$-secretase) in complex with an inhibitor OM00-3. Biochemistry 2002, 41:10963-10967.

64. Durham TB, Shepherd TA: Progress toward the discovery and development of efficacious BACE inhibitors. Curr Opin Drug Discov Dev 2006, 9:776-791.

65. Luo X, Yan R: Inhibition of BACE1 for therapeutic use in Alzheimer's disease. Int J Clin Exp Pathol 2010, 3:618-628.

66. Silvestri R: Boom in the development of non-peptidic beta-secretase (BACE1) inhibitors for the treatment of Alzheimer's disease. Med Res Rev 2009, 29:295-338

67. Fukumoto H, Takahashi H, Tarui N, Matsui J, Tomita T, Hirode M, Sagayama M, Maeda R, Kawamoto M, Hirai K, Terauchi J, Sakura Y, Kakihana M, Kato K, Iwatsubo T, Miyamoto M: A noncompetitive BACE1 inhibitor TAK-070 ameliorates $A B$ pathology and behavioral deficits in a mouse model of Alzheimer's disease. J Neurosci 2010, 30:11157-11166.

68. Malamas MS, Robichaud A, Erdei J, Quagliato D, Solvibile W, Zhou P, Morris K, Turner J, Wagner E, Fan K, Olland A, Jacobsen S, Reinhart P, Riddell D, Pangalos $M$ : Design and synthesis of aminohydantoins as potent and selective human beta-secretase (BACE1) inhibitors with enhanced brain permeability. Bioorg Med Chem Lett 2010, 20:6597-6605.

69. Sankaranarayanan S, Price EA, Wu G, Crouthamel MC, Shi XP, Tugusheva K Tyler KX, Kahana J, Ellis J, Jin L, Steele T, Stachel S, Coburn C, Simon AJ: In vivo $\beta$-secretase 1 inhibition leads to brain $A \beta$ lowering and increased asecretase processing of amyloid precursor protein without effect on neuregulin-1. J Pharmacol Exp Ther 2008, 324:957-969.
70. Truong AP, Toth G, Probst GD, Sealy JM, Bowers S, Wone DW, Dressen D, Hom RK, Konradi AW, Sham HL, Wu J, Peterson BT, Ruslim L, Bova MP, Kholodenko D, Motter RN, Bard F, Santiago P, Ni H, Chian D, Soriano F, Cole T, Brigham EF, Wong K, Zmolek W, Goldbach E, Samant B, Chen L, Zhang H, Nakamura DF, et al.: Design of an orally efficacious hydroxyethylamine (HEA) BACE-1 inhibitor in a preclinical animal model. Bioorg Med Chem Lett 2010, 20:6231-6236.

71. Sankaranarayanan S, Holahan MA, Colussi D, Crouthamel MC, Devanarayan V Ellis J, Espeseth A, Gates AT, Graham SL, Gregro AR, Hazuda D, Hochman JH, Holloway K, Jin L, Kahana J, Lai MT, Lineberger J, McGaughey G, Moore KP, Nantermet P, Pietrak B, Price EA, Rajapakse H, Stauffer S, Steinbeiser MA, Seabrook G, Selnick HG, Shi XP, Stanton MG, Swestock J, et al.: First demonstration of cerebrospinal fluid and plasma $A \beta$ lowering with oral administration of a $\beta$-site amyloid precursor protein-cleaving enzyme 1 inhibitor in nonhuman primates. J Pharmacol Exp Ther 2009, 328:131-140.

72. Alzheimer Research Forum [http://www.alzforum.org/new/detail. asp?id=1790]

73. Zhou L, Chavez-Gutierrez L, Bockstael K, Sannerud R, Annaert W, May PC, Karran E, De Strooper B: Inhibition of $\beta$-secretase in vivo via antibody binding to unique loops (D and F) of BACE1. J Biol Chem 2011, 286:8677-8687.

74. Arbel M, Yacoby I, Solomon B: Inhibition of amyloid precursor protein processing by $\beta$-secretase through site-directed antibodies. Proc Natl Acad SciUSA 2005, 102:7718-7723.

75. Rakover I, Arbel M, Solomon B: Immunotherapy against APP $\beta$-secretase cleavage site improves cognitive function and reduces neuroinflammation in Tg2576 mice without a significant effect on brain aß levels. Neurodegener Dis 2007, 4:392-402.

76. CChen C, Westenbroek RE, Xu X, Edwards CA, Sorenson DR, Chen Y, McEwen DP, O'Malley HA, Bharucha V, Meadows LS, Knudsen GA, Vilaythong A, Noebels JL, Saunders TL, Scheuer T, Shrager P, Catterall WA, Isom LL: Mice lacking sodium channel $\beta 1$ subunits display defects in neuronal excitability, sodium channel expression, and nodal architecture. J Neurosci 2004, 24:4030-4042.

77. Carlow DA, Gossens K, Naus S, Veerman KM, Seo W, Ziltener HJ: PSGL-1 function in immunity and steady state homeostasis. Immunol Rev 2009, 230:75-96

doi:10.1186/alzrt82

Cite this article as: Vassar R, Kandalepas PC: The $\beta$-secretase enzyme BACE1 as a therapeutic target for Alzheimer's disease. Alzheimer's Research \& Therapy 2011, 3:20 